\title{
DNA hypermethylation status of multiple genes in soft tissue sarcomas
}

\author{
Ken-ichi Kawaguchi ${ }^{1}$, Yoshinao Oda ${ }^{1}$, Tsuyoshi Saito ${ }^{1}$, Hidetaka Yamamoto ${ }^{1}$, \\ Tomonari Takahira $^{1}$, Chikashi Kobayashi ${ }^{1}$, Sadafumi Tamiya ${ }^{1}$, Naomi Tateishi ${ }^{1}$, \\ Yukihide Iwamoto ${ }^{2}$ and Masazumi Tsuneyoshi ${ }^{1}$ \\ ${ }^{1}$ Department of Anatomic Pathology, Pathological Sciences, Kyushu University, Fukuoka, Japan and \\ ${ }^{2}$ Department of Orthopaedic Surgery, Graduate School of Medical Sciences, Kyushu University, \\ Fukuoka, Japan
}

\begin{abstract}
The aberrant methylation of promoter CpG islands is known to be a major inactivation mechanism of tumorrelated genes. To determine the clinicopathological significance of gene promoter methylation in soft tissue sarcomas, we examined the promoter methylation status of 10 tumor-related genes in 65 soft tissue sarcomas and 19 adjacent non-neoplastic tissues by methylation-specific PCR. The methylation frequencies of tumorrelated genes tested in soft tissue sarcomas were $17(26 \%)$ for RASSF1A, $11(17 \%)$ for DAP kinase, $10(15 \%)$ for MGMT, nine (14\%) for GSTP1, eight (12\%) for PTEN, six (9\%) for p16 and $h M L H 1$, five (8\%) for $h M S H 2$, two (3\%) for $p 14$, and one (2\%) for $R B$. Promoter methylation of these genes was not recognized in non-neoplastic tissues. All those cases of soft tissue sarcoma that had MGMT methylation, with the exception of one case of malignant peripheral nerve sheath tumor, showed large tumor size $(\geq 10 \mathrm{~cm})$ or recurrence. Moreover, eight of 10 cases with MGMT methylation revealed high American Joint Committee on Cancer stage. Seven of 10 cases (70\%) with MGMT methylation showed a loss of MGMT expression by immunohistochemistry. In addition, MGMT methylation status had a statistically significant correlation with a loss of MGMT expression $(P=0.014)$. In conclusion, although methylation of tumor-related genes was a relatively rare event in soft tissue sarcomas, methylation was tumor-specific. Of 10 tumor-related genes, cases with MGMT methylation had a tendency to be aggressive behavior. Moreover, MGMT methylation was closely associated with a loss of MGMT expression. Although our findings need to be extending to a large series, promoter methylation of tumor-related genes is likely to have an association with the pathogenesis of soft tissue sarcomas. Furthermore, MGMT methylation may be associated with tumor aggressiveness and the inactivation of MGMT gene.
\end{abstract}

Modern Pathology (2006) 19, 106-114. doi:10.1038/modpathol.3800502; published online 21 October 2005

Keywords: soft tissue sarcoma; promoter hypermethylation; methylation-specific PCR; tumor-related genes

The pathogenesis of soft tissue sarcoma is unclear; however, some soft tissue sarcomas, such as synovial sarcoma and myxoid liposarcoma, frequently show specific balanced translocations as the sole cytogenetic anomaly, and their plausible contribution to pathogenesis has been suggested. On the other hand, soft tissue sarcomas without specific balanced translocations, such as leiomyosarcomas, malignant fibrous histiocytomas, and malignant peripheral nerve sheath tumors, are characterized by genetic changes, including complex karyotypic

Correspondence: Dr Y Oda, MD, Department of Anatomic Pathology, Pathological Sciences, Graduate School of Medical Sciences, Kyushu University, 3-1-1 Maidashi, Higashi-ku, Fukuoka, 812-8582, Japan.

E-mail: oda@surgpath.med.kyushu-u.ac.jp

Received 28 April 2005; revised and accepted 08 September 2005; published online 21 October 2005 changes and extensive heterogeneity; ${ }^{1-4}$ however, its frequencies are low.

The aberrant methylation of promoter-associated CpG islands has emerged as a distinct molecular pathway leading to cellular malignant transformation. Recent studies have demonstrated that the silencing of tumor suppressor genes by promoter hypermethylation is a common feature among many types of malignancies. ${ }^{5-7}$ It has been proposed that DNA methylation provides an alternate pathway to gene deletion or mutation. Some genes, such as the cell cycle inhibitor $p 16$, are hypermethylated across many tumor types, for example, colorectal, lung, and breast carcinomas, ${ }^{8-10}$ as well as bone and soft tissue sarcomas. ${ }^{11-18}$ According to recent studies demonstrating the role of methylation status in pathogenesis, we hypothesized that epigenetic abnormalities, particularly DNA hypermethylation, may play a primary role in the pathogenesis of soft 
tissue sarcomas in particular; here, we focused especially on cases lacking specific balanced translocation. However, it should be noted that the target genes inactivated by DNA methylation in soft tissue sarcomas remains largely unknown, and no global profile of $\mathrm{CpG}$ island methylation in soft tissue sarcomas has yet emerged.

To explore the role of DNA methylation in soft tissue sarcomas, we selected 10 tumor-related genes, the frequently silenced by aberrant methylation in a number of tumor types, and examined the methylation status for the following genes by methylation-specific PCR: RASSF1A, p16, p14, RB, hMLH1, hMSH2, MGMT, GSTP1, PTEN, and death-associated protein kinase (DAP kinase). We also analyzed the correlation between the methylation status of these genes and the clinicopathologic features known to be important for the prognosis of cases of soft tissue sarcoma.

\section{Materials and methods}

\section{Tumor Samples and DNA Extraction}

Snap-frozen tumor samples from 65 soft tissue sarcoma cases and 19 adjacent non-neoplastic tissues were obtained from the collection of softtissue tumors registered in the Department of Anatomic Pathology, Pathological Sciences, Graduate School of Medical Sciences, Kyushu University, Japan. Fresh tumor samples were carefully dissected from the tumors in order to exclude the surrounding normal tissue, and the samples were immediately frozen in liquid nitrogen and stored at $-80^{\circ} \mathrm{C}$. Diagnosis in each of the 65 cases was based on light microscopic examination of hematoxylineosin-stained paraffin blocks. Smooth muscle differentiation of leiomyosarcomas was confirmed by immunohistochemical positive reaction for desmin, muscle-specific actin, and alpha smooth muscle actin. Malignant peripheral nerve sheath tumors showed positive immunoreactivity for S-100 protein, and solitary fibrous tumors were revealed for CD34. One case of fibrosarcoma was positive for vimentin but negative for myogenic markers, S-100 protein, CD34, cytokeratins, and epithelial membrane antigen. In addition, no SYT-SSX fusion gene was recognized in this case. Histologic diagnosis of the 65 cases of soft tissue sarcoma included this study revealed 32 cases of malignant fibrous histiocytoma (pleomorphic type, 24 cases; myxoid type, eight cases), 17 cases of malignant peripheral nerve sheath tumor, 13 cases of leiomyosarcoma, two cases of solitary fibrous tumor (one of which was malignant), and one case of fibrosarcoma. Five of 17 malignant peripheral nerve sheath tumor cases occurred in association with neurofibromatosis type 1 . As regards the staging of primary tumors, cases were also evaluated according to the new American Joint Committee on Cancer (AJCC) staging system. ${ }^{19}$ Genomic DNA was purified using standard proteinase $\mathrm{K}$ digestion and phenol/ chloroform extraction methods.

\section{Bisulfite Modification and Methylation-Specific PCR}

Bisulfite modification was performed using a DNA modification kit (Intergen). DNA $(1 \mu \mathrm{g})$ in a volume of $100 \mu \mathrm{l}$ was denatured by $\mathrm{NaOH} 0.2 \mathrm{M}$ for $10 \mathrm{~min}$ at $37^{\circ} \mathrm{C}$. Salmon sperm DNA ( $\left.1 \mu \mathrm{g}\right)$ (Sigma) was added as a carrier before modification. In all, $550 \mu \mathrm{l}$ of freshly prepared $3 \mathrm{M}$ sodium bisulfite at $\mathrm{pH} 5$ was added and mixed with the samples, which were then incubated at $50^{\circ} \mathrm{C}$ for $16 \mathrm{~h}$. Modified DNA was purified using Wizard DNA purification resin according to the manufacturer's instructions (Promega). Samples were eluted into $50 \mu \mathrm{l}$ of water, and modification was completed by $\mathrm{NaOH} 0.3 \mathrm{M}$ treatment for $5 \mathrm{~min}$ at room temperature, followed by ethanol precipitation. The DNA was resuspended in water and used immediately or stored at $-20^{\circ} \mathrm{C}$. The sequences of the primers and annealing temperatures are summarized in Table 1. Negative control samples without DNA were included for each set of PCR. Each PCR product $(10 \mu \mathrm{l})$ was directly loaded onto $2 \%$ agarose gel, stained with ethidium bromide, and directly visualized under UV illumination.

\section{Immunohistochemistry}

Immunohistochemical analysis was performed using mouse IgG monoclonal antibodies against MGMT (1:50, Santa Cruz Biotechnology, USA). Sections of formalin-fixed, paraffin-embedded tissue ( $4 \mu \mathrm{m}$ thick) were deparaffinized in xylene and dehydrated in ethanol. After dehydration, the endogenous peroxidase was blocked by methanol containing $3 \% \mathrm{H}_{2} \mathrm{O}_{2}$ for $30 \mathrm{~min}$. For staining with the above antibody, specimens were pretreated with citrate buffer $(0.01 \mathrm{~mol} / \mathrm{l}$ citric acid, $\mathrm{pH}$ 6.0) four times, and each pretreatment was carried out for $5 \mathrm{~min}$ at $100^{\circ} \mathrm{C}$ in a microwave oven. Sections were incubated with the primary antibody at $4^{\circ} \mathrm{C}$ overnight, followed by staining with a streptavidinbiotin-peroxidase kit (Nichirei, Tokyo, Japan). The sections were reacted in a $3,3^{\prime}$ diaminobenzidine, peroxytrichloride substrate solution, counterstained with hematoxylin and mounted. MGMT expression was considered as lost when the distribution of stained cells amounted to less than $10 \%$ of the tumor cells. ${ }^{28}$

\section{Statistical Analysis}

Fisher's exact test was used to evaluate the association between two dichotomous variables. A $P$-value of $<0.05$ was considered to indicate statistical significance.

\section{Results}

\section{Clinical and Histological Findings}

The clinicopathologic data for 65 soft tissue sarcoma cases are summarized in Table 2. According 
Table 1 Primers used for the analysis of methylation of 10 tumor-related genes

\begin{tabular}{|c|c|c|c|c|}
\hline \multirow[t]{2}{*}{ Determination } & \multicolumn{2}{|c|}{ Primer sequence ( $5^{\prime}$ to $\left.3^{\prime}\right)$} & \multirow[t]{2}{*}{$A T\left({ }^{\circ} \mathrm{C}\right)$} & \multirow[t]{2}{*}{ References } \\
\hline & Sense & Antisense & & \\
\hline \multicolumn{5}{|l|}{ RASSF1A } \\
\hline $\mathrm{M}$ & GTGTTAACGCGTTGCGTATC & AACCCCGCGAACTAAAAACGA & 60 & 20 \\
\hline $\mathrm{U}$ & TTTGGTTGGAGTGTGTTAATGTG & CAAACCCCACAAACTAAAAACAA & 60 & \\
\hline \multicolumn{5}{|l|}{$D A P$ kinase } \\
\hline $\mathrm{M}$ & GGATAGTCGGATCGAGTTAACGTC & CCСTCCCAAACGCCG & 55 & 21 \\
\hline $\mathrm{U}$ & GGAGGATAGTTGGATTGAGTTATTGTT & CAAATCССТСССАAАСАССАА & 55 & \\
\hline \multicolumn{5}{|l|}{ MGMT } \\
\hline M & TTTCGACGTTCGTAGGTTTTCGC & GCACTCTTCCGAAAACGAAACG & 59 & 7 \\
\hline $\mathrm{U}$ & TTTGTGTTTTGATGTTTGTAGGTTTTTGT & AACTCCACACTCTTCCAAAAACAAAACA & 59 & \\
\hline \multicolumn{5}{|l|}{ GSTP1 } \\
\hline M & TTCGGGGTGTAGCGGTCGTC & GCCCCAATACTAAATCACGACG & 59 & 22 \\
\hline $\mathrm{U}$ & GATGTTTGGGGTGTAGTGGTTGTT & CCACCCCAATACTAAATCACAACA & 59 & \\
\hline \multicolumn{5}{|l|}{ PTEN } \\
\hline $\mathrm{M}$ & GTTTGGGGATTTTTTTTTCGC & AACCCTTCCTACGCCGCG & 60 & 23 \\
\hline $\mathrm{U}$ & TATTAGTTTGGGGATTTTTTTTTTGT & СССААСССТТССТАСАССАСА & 60 & \\
\hline \multicolumn{5}{|c|}{ 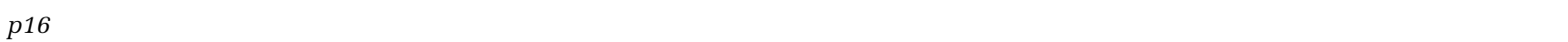 } \\
\hline $\mathrm{M}$ & TTATTAGAGGGTGGGGCGGATCGC & GACCCCGAACCGCGACCGTAA & 65 & 17 \\
\hline $\mathrm{U}$ & TTATTAGAGGGTGGGGTGGATTGT & CAACCCCAAACCACAACCATAA & 65 & \\
\hline \multicolumn{5}{|l|}{$h M L H 1$} \\
\hline $\mathrm{M}$ & ACGTAGACGTTTTATTAGGGTCGC & CCTCATCGTAACTACCCGCG & 59 & 24 \\
\hline $\mathrm{U}$ & TTTTGATGTAGATGTTTTATTAGGGTTGT & ACСACСТCATCATAACTACССACA & 59 & \\
\hline \multicolumn{5}{|l|}{ hMSH2 } \\
\hline $\mathrm{M}$ & TCGTGGTCGGACGTCGTTC & CAACGTCTCСTTCGACTACACCG & 59 & 25 \\
\hline $\mathrm{U}$ & GGTTGTTGTGGTTGGATGTTGTTT & САAСATСТССТTCAАСТАСАССА & 59 & \\
\hline \multicolumn{5}{|l|}{ p14 } \\
\hline $\mathrm{M}$ & GTGTTAAAGGGCGGCGTAGC & AAAACCCTCACTCGCGACGA & 60 & 26 \\
\hline $\mathrm{U}$ & TTTTTGGTGTTAAAGGGTGGTGTAGT & СACAAAAACССТСACTCACAACAA & 60 & \\
\hline \multicolumn{5}{|l|}{$R B$} \\
\hline M & GGGAGTTTCGCGGACGTGAC & ACGTCGAAACACGCCCCG & 55 & 27 \\
\hline $\mathrm{U}$ & GGGAGTTTTGTGGATGTGAT & ACATCAAAACACACCCCA & 55 & \\
\hline
\end{tabular}

M: methylated; U: unmethylated; AT: anneling temperature.

to the case breakdown, 29 patients were affected in thigh, seven in buttock, six in retroperitoneum, four each in upper arm and knee, three in forearm, two in elbow, and one in each of the following: chest wall, scapular region, axilla, posterior mediastinum, sacral region, pelvic cavity, inguinal region, ankle, finger, and spinal cord. The AJCC stage was evaluable in 50 cases. Two cases were considered to be AJCC stage I, 30 cases were stage II, 16 cases were stage III, and two cases were stage IV.

\section{Frequency of Promoter Hypermethylation of Tumor-Related Genes in Soft Tissue Sarcomas}

The frequency of methylation of the 10 tumorrelated genes in 65 soft tissue sarcomas is detailed in Figure 1. Among 65 soft tissue sarcomas, the methylation percentages (in descending order) were as follows: $17(26 \%)$ for RASSF1A, $11(17 \%)$ for DAP kinase, 10 (15\%) for MGMT, 9 (14\%) for GSTP1, $8(12 \%)$ for PTEN, $6(9 \%)$ for $p 16$ and $h M L H 1,5(8 \%)$ for $h M S H 2,2(3 \%)$ for $p 14$, and 1 ( $2 \%$ ) for $R B$ (Table 3 ). All cases of soft tissue sarcoma with promoter hypermethylation showed both ummethylated and methylated signals (Figure 2). As regards the subtypes of soft tissue sarcoma, no statistically significant correlation was found between the subtypes of soft tissue sarcoma and the methylation status of these tumor-related genes. Most tumors (42 of $65,(65 \%)$ ) showed promoter methylation in at least one of the 10 tumor-related genes. In all, 13 tumors $(20 \%)$ displayed hypermethylation of three or more genes. Promoter hypermethylation of the 10 tumor-related genes examined was not observed in any of the nonneoplastic tissues examined. 
Table 2 Clinicopathologic parameters in 65 soft tissue sarcomas

\begin{tabular}{lc}
\hline Clinicopathological characteristics & Cases \\
\hline Median age (range) & 59.6 (1-93) \\
Sex & \\
Male & 28 \\
Female & 37 \\
Location & \\
Thigh & 29 \\
Buttock & 7 \\
Retroperitoneum & 6 \\
Upper arm & 4 \\
Knee & 4 \\
Forearm & 3 \\
Elbow & 2 \\
Others & 10 \\
Median size, cm (range) & \\
Tumor type & $(2-26)$ \\
Primary tumors & 50 \\
Local recurrences & 15 \\
Histological subtype & \\
Malignant fibrous histiocytoma & \\
Malignant peripheral nerve sheath tumor & 32 \\
Leiomyosarcoma & 17 \\
others & 13 \\
AJCC stage & 3 \\
I and II & \\
III and IV & 32 \\
\hline
\end{tabular}

${ }^{a} n=50$.

\section{Correlation with Clinical Parameters}

The correlation between methylation status and the clinicopathological parameters is given in Table 4 . We excluded $p 14$ and $R B$ genes from the analysis because the frequency of methylation in these genes was very low. All those cases with MGMT methylation, with the exception of one case of malignant peripheral nerve sheath tumor, showed large tumor size $(\geq 10 \mathrm{~cm})$ or recurrence (Table 5). Moreover, eight of 10 cases with MGMT methylation revealed high AJCC stage. With regard to other tumor-related genes, there was no relationship between methylation status and clinicpathologic parameters. Although survival data were available for 38 cases, no patients with MGMT methylation showed an association with poor survival statistically because some cases in which the follow-up interval was too short were included in these series. With regard to p16 methylation, although we reported previously that $p 16$ methylation was observed in $22 \%$ of the leiomyosarcoma cases examined, ${ }^{17}$ in the current study, p16 methylation was also detected in three out of 13 leiomyosarcoma cases (23\%). Leiomyosarcoma appeared with a higher frequency than the other spindle-shaped sarcomas (6\%); however, no statistically significant correlation was observed in this regard. With regard to the cases of malignant peripheral nerve sheath tumor, no differences were observed between sporadic and neurofibromatosis type-1-associated cases. There was no correlation of methylation status with tumor grade, patients age, and tumor cytogenetics.

\section{Immunohistochemical Analysis of MGMT}

The inactivation of MGMT-involved promoter methylation was examined here because almost those cases with MGMT methylation showed large tumor size and high AJCC stage, which are known as factors of tumor aggressiveness in cases of soft tissue sarcoma. Thus, we investigated the expression of MGMT protein using immunohistochemical analysis. In 50 cases, paraffin-embedded tissues were available for analysis; 10 of these cases were found to have MGMT methylation, whereas the remaining 40 cases lacked $M G M T$ methylation. Of the 50 soft tissue sarcoma cases, $13(26 \%)$ showed a loss of MGMT expression. Seven of the 10 cases $(70 \%)$ with MGMT methylation showed a loss of MGMT expression, on the contrary, six of the 40 soft tissue sarcoma cases (15\%) without MGMT methylation revealed a loss of MGMT expression (Figure $3 \mathrm{a}$ and b). There was a statistically significant correlation between MGMT methylation and a loss of MGMT expression $(P=0.014)$ (Table 6).

\section{Discussion}

The pathogenesis remains unaccounted for in soft tissue sarcomas without specific balanced translocations, such as leiomyosarcomas, malignant fibrous histiocytomas, and malignant peripheral nerve sheath tumors. In these cases, genetic changes such as chromosomal deletions and mutations have been reported; ${ }^{1-4}$ however, such changes are relatively rare, and associations with other mechanisms have been considered in this context. An epigenetic factor, that is, transcriptional silencing by the hypermethylation of $\mathrm{CpG}$ islands in the promoter region, is becoming recognized as a common mechanism for the inactivation of tumor suppressor genes in human malignancies. ${ }^{29,30}$ Recently, the growing list of genes inactivated by promoter hypermethylation has provided a reason to examine the epigenetic alteration of multiple tumor-related genes in various types of malignancy. In the present study, we analyzed the methylation characteristics of patients with soft tissue sarcoma and investigated possible associations between aberrant methylation and clinical characteristics; to this end, we examined the methylation status of 10 tumor-related genes in patients with soft tissue sarcoma.

The profile of promoter methylation for the genes differs for each tumor types, providing a tumor-type and gene specific profile. In cancers, some genes, such as p16, are methylated across many tumors, on the contrary, the methylation of certain genes reflects their very specific involvement in selected 


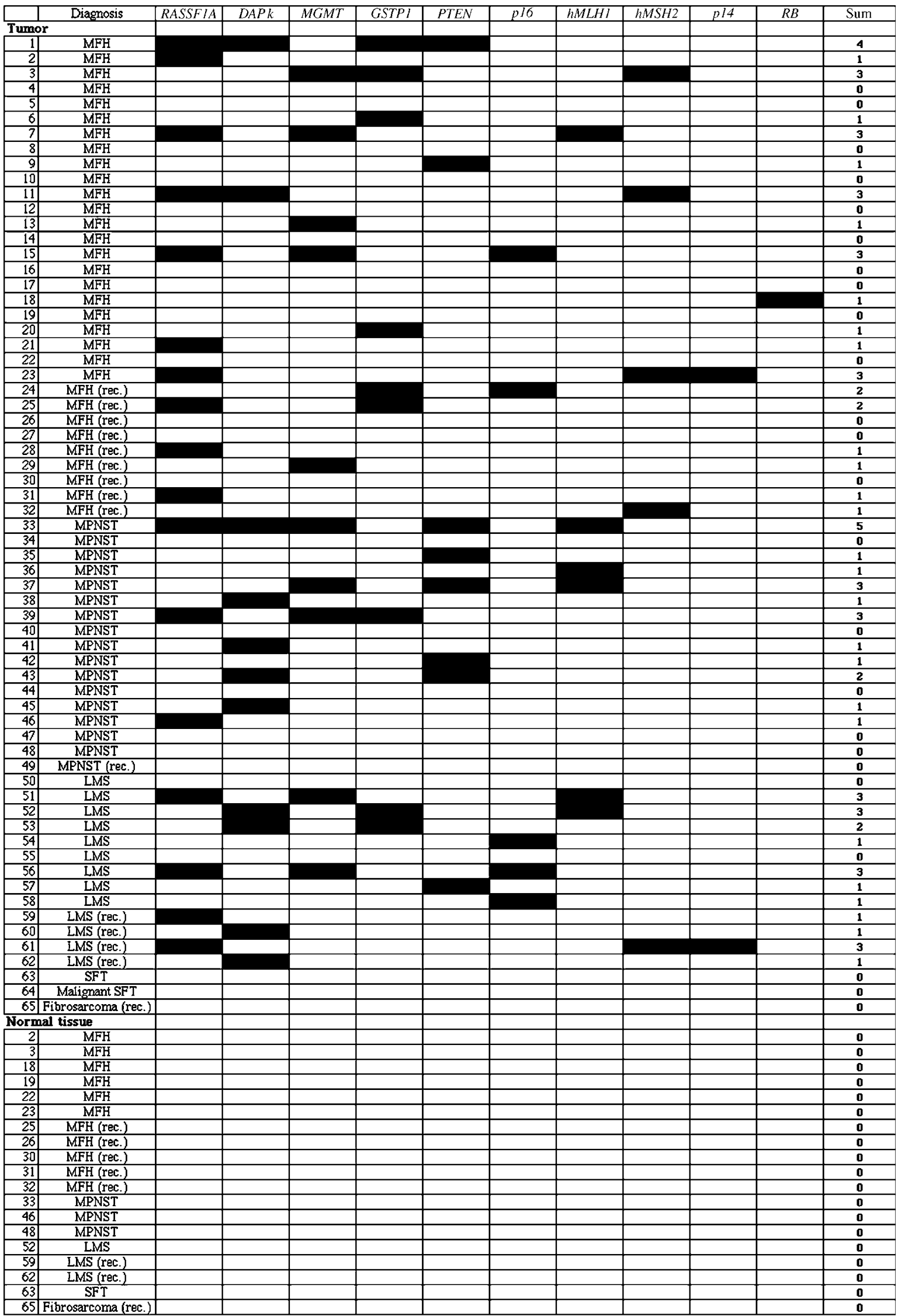

MFH; Malignant fibrous histiocytoma, MPNST; Malignant peripheral nerve sheath tumor, LMS; Leiomyosarcoma, SFT; Solitary fibrous tumor rec.; recurrence 
Table 3 Frequency of 10 tumor-related genes methylation in soft tissue sarcomas $(n=65)$

\begin{tabular}{|c|c|c|c|c|c|}
\hline \multirow[t]{2}{*}{ Genes } & \multicolumn{4}{|c|}{ Subtypes of soft tissue sarcomas } & \multirow[t]{2}{*}{ Total } \\
\hline & $\begin{array}{l}\text { Malignant fibrous } \\
\text { histiocytoma } \\
(\mathrm{n}=32)\end{array}$ & $\begin{array}{c}\text { Malignant } \\
\text { peripheral nerve } \\
\text { sheath tumor } \\
(\mathrm{n}=17)\end{array}$ & $\begin{array}{l}\text { Leiomyosarcoma } \\
\qquad(\mathrm{n}=13)\end{array}$ & Others $(\mathrm{n}=3)$ & \\
\hline$R A S S F 1 A$ & $10(31 \%)$ & $3(18 \%)$ & $4(31 \%)$ & 0 & $17(26 \%)$ \\
\hline DAP kinase & $2(6 \%)$ & $5(29 \%)$ & $4(31 \%)$ & 0 & $11(17 \%)$ \\
\hline$M G M T$ & $5(16 \%)$ & $3(18 \%)$ & $2(15 \%)$ & 0 & $10(15 \%)$ \\
\hline GSTP1 & $6(19 \%)$ & $1(6 \%)$ & $2(15 \%)$ & 0 & $9(14 \%)$ \\
\hline PTEN & $2(6 \%)$ & $5(29 \%)$ & $1(8 \%)$ & 0 & $8(12 \%)$ \\
\hline$p 16$ & $2(6 \%)$ & 0 & $3(23 \%)$ & $1(33 \%)$ & $6(9 \%)$ \\
\hline$h M L H 1$ & $1(3 \%)$ & $3(18 \%)$ & $2(15 \%)$ & 0 & $6(9 \%)$ \\
\hline hMSH2 & $4(13 \%)$ & 0 & $1(8 \%)$ & 0 & $5(8 \%)$ \\
\hline$p 14$ & $1(3 \%)$ & 0 & $1(8 \%)$ & 0 & $2(3 \%)$ \\
\hline$R B$ & $1(3 \%)$ & 0 & 0 & 0 & $1(2 \%)$ \\
\hline
\end{tabular}

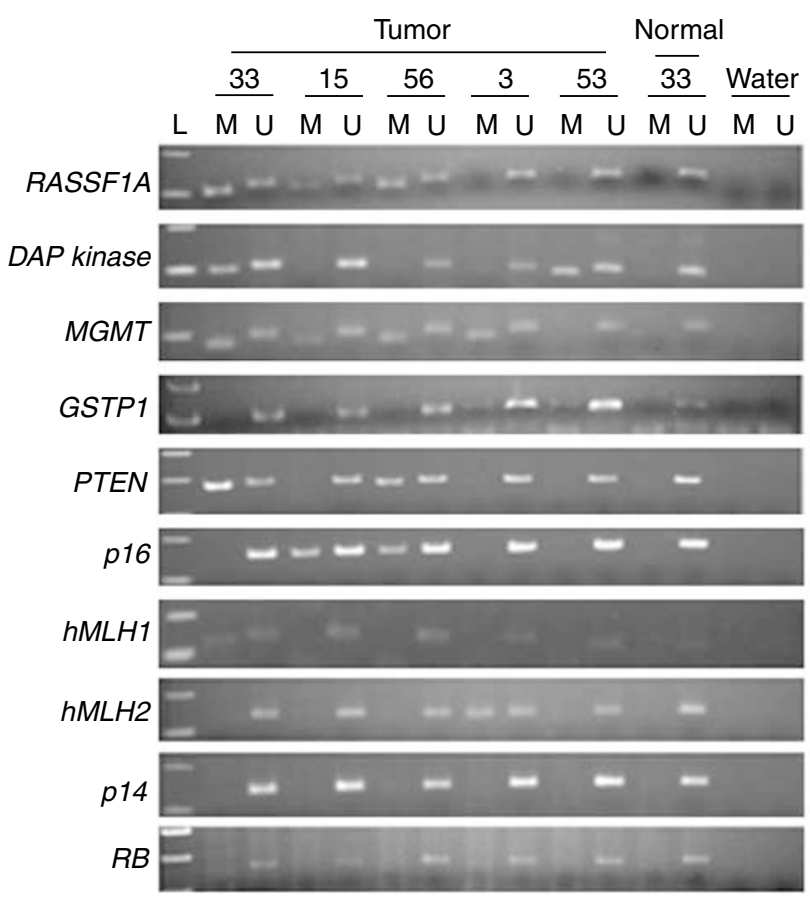

Figure 2 Methylation status of the promoter region of 10 tumorrelated genes as determined by methylation-specific PCR. PCR products were amplified by unmethylated (U) and methylated (M)-specific primers.

tumor types. Of the 10 genes studied, we found that $R A S S F 1 A$ gene was methylated at $26 \%$ of soft tissue sarcoma cases examined. Harada et $a l^{16}$ also reported that $R A S S F 1 A$ methylation was frequently seen in pediatric tumors, including some types of sarcoma $(40 \%)$. On the other hand, the frequencies of other nine genes methylation (DAP kinase, MGMT, GSTP1, PTEN, p16, hMLH1, hMSH2, p14, and $R b$ ) were low if ever methylated. Seidel et $a l^{18}$ reported that $R A S S F 1 A$ methylation was more frequent in leiomyosarcoma compared to other type soft tissue sarcomas. Our result had no association between methylation status and the subtype of soft tissue sarcomas. In the current study, more than half of tumors examined (65\%) showed promoter methylation in at least one of the 10 tumor-related genes. In addition, methylation was absent in corresponding nonmalignant tissue, indicating that methylation was tumor-specific. These results suggest that promoter methylation may play an important role with the pathogenesis of soft tissue sarcomas.

$M G M T$ is a DNA repair protein that remove mutagenic and cytotoxic adducts from O6-guanine in DNA. ${ }^{31}$ Although the deletion or mutation of the MGMT gene is rare, frequent methylation of this gene is associated with the gene silencing demonstrated in human cancers. ${ }^{32-35}$ As regards sarcomas, a previous report demonstrated that promoter hypermethylation of the MGMT gene was a rare event. ${ }^{16}$ Similarly, the present study also revealed that MGMT methylation occurred in 10 out of 65 soft tissue sarcoma cases (15\%). Although the number of methylated cases is relatively low, nine of 10 cases with MGMT methylation showed large tumor size $(\geq 10 \mathrm{~cm})$ or recurrence, and eight cases revealed high AJCC stage. In addition, seven of 10 cases $(70 \%)$ with MGMT methylation showed a loss of MGMT expression, and MGMT methylation was closely correlated with a loss of MGMT expression. Although the presence of loss of heterozygosity (LOH) should be checked, these results indicate that the epigenetic inactivation of MGMT may play an important role in tumor aggressiveness in the case of soft tissue sarcomas. In this study, three cases with promoter methylation showed preserved

Figure 1 Methylation profiles of 10 tumor-related genes in 65 soft tissue sarcomas and 19 adjacent normal tissues. A filled box (black box) indicates that promoter methylation was detected by methylation-specific PCR and an open box (white box) indicates that no methylation was detected. 
Table 4 Correlation between methylation status and clinicopathological parameters in 65 soft tissue sarcomas

\begin{tabular}{|c|c|c|c|c|c|c|c|c|}
\hline & RASSF1A & DAP kinase & MGMT & GSTP1 & PTEN & p16 & hMLH1 & hMSH2 \\
\hline \multicolumn{9}{|l|}{ Age (years) } \\
\hline$\geq 60(n=36)$ & $11(31 \%)$ & $4(11 \%)$ & $7(19 \%)$ & $7(19 \%)$ & $3(8 \%)$ & $4(11 \%)$ & $3(8 \%)$ & $4(11 \%)$ \\
\hline$<60(n=29)$ & $6(21 \%)$ & $7(24 \%)$ & $3(10 \%)$ & $2(7 \%)$ & $5(17 \%)$ & $2(7 \%)$ & $3(10 \%)$ & $1(3 \%)$ \\
\hline \multicolumn{9}{|l|}{ Gender } \\
\hline $\mathrm{M}(n=28)$ & $9(32 \%)$ & $5(18 \%)$ & $6(21 \%)$ & $3(11 \%)$ & $4(14 \%)$ & $4(14 \%)$ & $5(18 \%)$ & $4(14 \%)$ \\
\hline $\mathrm{F}(n=37)$ & $8(22 \%)$ & $6(16 \%)$ & $4(11 \%)$ & $6(16 \%)$ & $4(11 \%)$ & $2(5 \%)$ & $1(3 \%)$ & $1(3 \%)$ \\
\hline \multicolumn{9}{|l|}{ Tumor size $(\mathrm{cm})$} \\
\hline$\geq 10(n=19)$ & 7 (37\%) & $4(21 \%)$ & $8(42 \%)$ & $1(5 \%)$ & $2(11 \%)$ & $2(11 \%)$ & $4(21 \%)$ & $3(16 \%)$ \\
\hline$<10(n=46)$ & $10(22 \%)$ & $7(15 \%)$ & $2(4 \%)$ & $8(17 \%)$ & $6(13 \%)$ & $4(9 \%)$ & $2(4 \%)$ & $2(4 \%)$ \\
\hline \multicolumn{9}{|l|}{ Tumor type } \\
\hline Primary $(n=50)$ & $12(24 \%)$ & $9(18 \%)$ & $9(18 \%)$ & $7(14 \%)$ & $8(16 \%)$ & $5(10 \%)$ & $6(12 \%)$ & $3(6 \%)$ \\
\hline Recurrece $(n=15)$ & $5(33 \%)$ & $2(13 \%)$ & $1(7 \%)$ & $2(13 \%)$ & 0 & $1(7 \%)$ & 0 & $2(13 \%)$ \\
\hline \multicolumn{9}{|l|}{ AJCC stage $\mathrm{e}^{\mathrm{a}}$} \\
\hline I and II $(n=32)$ & $5(16 \%)$ & $5(16 \%)$ & $1(3 \%)$ & $4(13 \%)$ & $6(19 \%)$ & $4(13 \%)$ & $2(6 \%)$ & $2(6 \%)$ \\
\hline III and IV $(n=18)$ & $7(39 \%)$ & $4(22 \%)$ & $8(44 \%)$ & $3(17 \%)$ & $2(11 \%)$ & $1(6 \%)$ & $4(22 \%)$ & $1(6 \%)$ \\
\hline
\end{tabular}

${ }^{\mathrm{a}} n=50$.

Table 5 Clinicopathologic findings of 10 soft tissue sarcoma cases with MGMT methylation $(n=10)$

\begin{tabular}{lcclclll}
\hline Cases & Age (years) & Sex & Location & Tumor size $(\mathrm{cm})$ & Tumor type & Histological subtype & AJCC stage \\
\hline Case 3 & 62 & M & Thigh & 10 & Primary & Malignant fibrous histiocytoma \\
Case 7 & 93 & M & Upper arm & 21 & Primary & Malignant fibrous histiocytoma & III \\
Case 13 & 81 & F & Buttock & 11 & Primary & Malignant fibrous histiocytoma & III \\
Case 15 & 67 & M & Retroperitoneum & 10 & Primary & Malignant fibrous histiocytoma & III \\
Case 29 & 87 & F & Forearm & 8 & Recurrence & Malignant fibrous histiocytoma & NA \\
Case 33 & 27 & F & Buttock & 15 & Primary & Malignant peripheral nerve sheath tumor & III \\
Case 37 & 47 & M & Knee & 15 & Primary & Malignant peripheral nerve sheath tumor & III \\
Case 39 & 77 & F & Mediastinum & 4 & Primary & Malignant peripheral nerve sheath tumor & II \\
Case 51 & 84 & M & Thigh & 16 & Primary & Leiomyosarcoma & III \\
Case 56 & 55 & M & Retroperitoneum & 26 & Primary & Leiomyosarcoma & III \\
\hline
\end{tabular}

NA: not available.

expression of the MGMT protein. The present findings suggest the possibility that MGMT methylation occurred in only one allele. In addition, another explanation could be that the MSP is too sensitive and that the methylation will concern only a subclone of the tumor.

The frequency of the promoter methylation of p16 was observed in $0-35 \%$ of cases studied in soft tissue and bone sarcomas, including those included in our previous report. ${ }^{1-18}$ Furthermore, we previously demonstrated that $p 16$ methylation played an important role in the inactivation of $p 16$ gene in soft tissue leiomyosarcomas. ${ }^{17}$ In the current study, the promoter hypermethylation of $p 16$ was observed in three out of 13 leiomyosarcoma cases $(23 \%)$, and this was found to be a relatively frequent event, in comparison to the incidence of such hypermethylation associated with other types of soft tissue sarcomas (6\%); however, in this regard, no statistically significant correlation was observed.

In conclusion, the present findings indicated that the frequency of promoter hypermethylation of tumor-related genes was not high in spindleshaped sarcomas, that is, in cases without specific balanced translocations such as those of malignant fibrous histiocytoma, leiomyosarcoma, and malignant peripheral nerve sheath tumor. Methylation was absent in the corresponding nonmalignant tissues examined, confirming that methylation was tumor-specific. Among the 10 tumor-related genes studied, cases with MGMT methylation showed large tumor size and high AJCC stage. In addition, MGMT methylation was closely correlated with a loss of MGMT expression. These findings indicate that MGMT methylation may play an important role in tumor aggressiveness of soft tissue sarcoma and the inactivation of MGMT gene; however, a length follow-up will be required to determine whether methylation is a predictive factor for survival. Although the sample size should be increased in further studies of this nature, the present results suggest that the promoter methylation of tumorrelated genes may be associated with the pathogenesis of soft tissue sarcomas. 

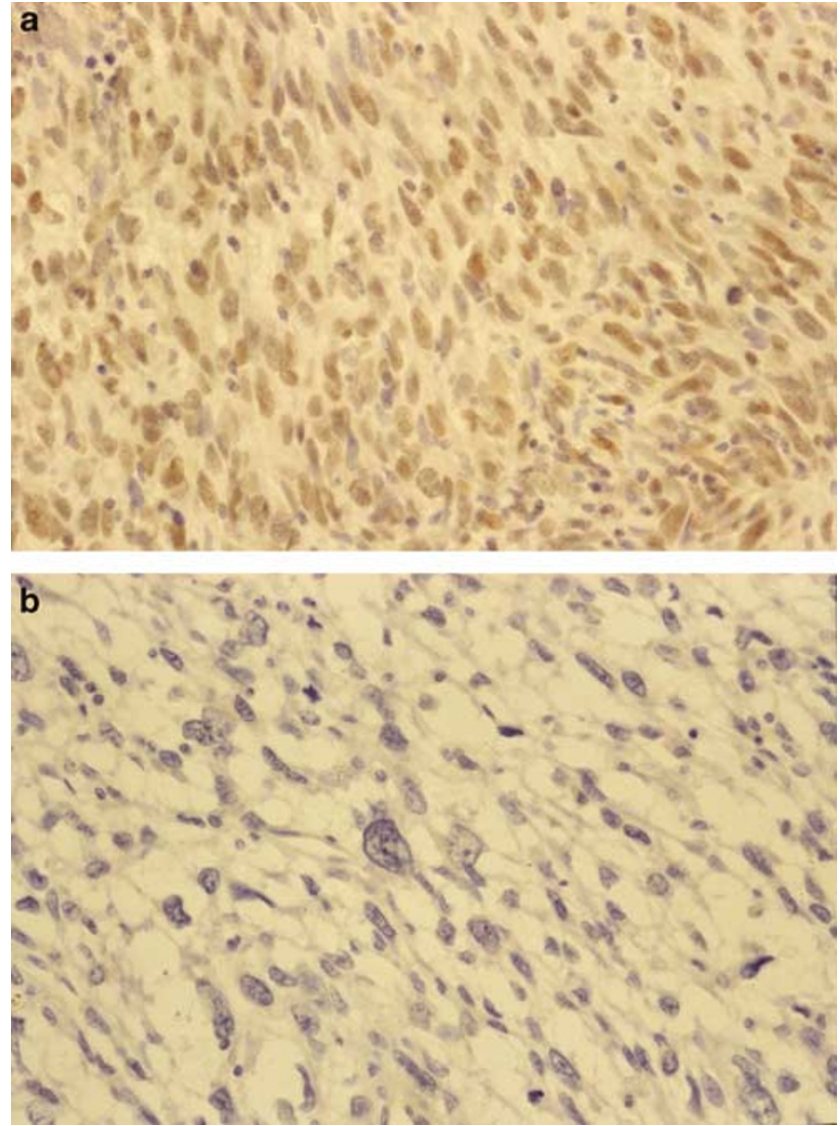

Figure 3 Immunohistochemical staining of MGMT. (a) Immunohistochemistry showing nuclear staining in the majority of tumor cells (Case 40, malignant peripheral nerve sheath tumor). No promoter methylation of the MGMT gene was detected in this case. (b) A loss of MGMT expression was recognized in the majority of tumor cells. This case was revealed as having promoter methylation of MGMT (Case 15, malignant fibrous histiocytoma).

Table 6 Correlation between MGMT methylation and MGMT expression in soft tissue sarcomas $(n=50)$

\begin{tabular}{lccc}
\hline MGMT methylation & \multicolumn{2}{c}{ MGMT expression } & P-value \\
\cline { 2 - 3 } & Loss & Normal & \\
\hline+ & 7 & 3 & $P=0.014^{*}$ \\
- & 6 & 34 & \\
\hline
\end{tabular}

Fisher's exact test.

${ }^{*}$ Statistically significant.

\section{Acknowledgements}

We are grateful to Miss Y Nouzuka and Miss N Tateishi for their excellent technical assistance. The English used in this manuscript was revised by KN International. Grant sponsors: This work was supported in part by a Grant-in-Aid for Scientific Research (C) (no. 15590304) from the Japan Society for the Promotion of Science, Tokyo, Japan.

\section{References}

1 El-Rifai W, Sarlomo-Rikala M, Knuutila S, et al. DNA copy number change in development and progression in leiomyosarcoma of soft tissues. Am J Pathol 1998; 153:985-990.

2 Plaat BE, Molenaar WM, Mastik MF, et al. Computerassisted cytogenetic analysis of 51 malignant peripheral-nerve-sheath tumors: sporadic vs neurofibromatosis-type-1-associated malignant schwannomas. Int J Cancer 1999;83:171-178.

3 Chibon F, Mairal A, Freneaux P, et al. The RB1 gene is the target of chromosome 13 deletions in malignant fibrous histiocytoma. Cancer Res 2000;60:6339-6345.

4 Derre J, Lagace R, Nicolas A, et al. Leiomyosarcomas and most malignant fibrous histiocytomas share very similar comparative genomic hybridization imbalances: an analysis of a series of 27 leiomyosarcomas. Lab Invest 2001;81:211-215.

5 Baylin SB, Herman JG, Graff JR, et al. Alterations in DNA methylation: a fundamental aspect of neoplasia. Adv Cancer Res 1998;72:141-146.

6 Costello JF, Fruhwald MC, Smiraglia DJ, et al. Aberrant CpG-island methylation has non-random and tumortype-specific patterns. Nat Genet 2000;24:132-138.

7 Esteller M, Corn PG, Baylin SB, Herman JG. A gene hypermethylation profile of human cancer. Cancer Res 2001;61:3225-3229.

8 Gonzalez-Zulueta M, Bender CM, Yang AS, et al. Methylation of the $5^{\prime} \mathrm{CpG}$ island of the $p 16 / C D K N 2$ tumor-suppressor gene in normal and transformed human tissues correlates with gene silencing. Cancer Res 1995;55:4531-4535.

9 Herman JG, Merlo A, Mao L, et al. Inactivation of the CDKN2/p16/MTS1 gene is frequently associated with aberrant DNA methylation in all common human cancers. Cancer Res 1995;55:4525-4530.

10 Merlo A, Herman JG, Mao L, et al. 5' CpG island methylation is associated with transcriptional silencing of the tumour suppressor p16/CDKN2/MTS1 in human cancers. Nat Med 1995;1:686-692.

11 Benassi MS, Molendini L, Gamberi G, et al. Alteration of $\mathrm{pRB} / \mathrm{p} 16 / \mathrm{cdk} 4$ regulation in human osteosarcoma. Int J Cancer 1999;84:489-493.

12 Orlow I, Drobnjak M, Zhang Z, et al. Alterations of $I N K 4 A$ and $I N K 4 B$ genes in adult soft tissue sarcomas: Effect on survival. J Natl Cancer Inst 1999;91:73-79.

13 Wei G, Lonardo F, Ueda T, et al. CDK4 gene amplification in osteosarcoma: reciprocal relationship with INK4A gene alterations and mapping of $12 q 13$ amplicons. Int J Cancer 1999;80:199-204.

14 Benassi MS, Molendini L, Gamberi G, et al. Involvement of INK4A gene products in the pathogenesis and development of human osteosarcoma. Cancer 2001;15: 3062-3067.

15 Lopez-Guerrero JA, Pellin A, Noguera R, et al. Molecular analysis of the 9p21 locus and p53 genes in Ewing family tumors. Lab Invest 2001;81:803-814.

16 Harada K, Toyooka S, Maitra A, et al. Aberrant promoter methylation and silencing of the RASSF1A gene in pediatric tumors and cell lines. Oncogene 2002;21:4345-4349.

17 Kawaguchi K, Oda Y, Saito T, et al. Mechanisms of inactivation of $p 16$ gene in leiomyosarcoma of soft tissue: A decrease expression of p16 expression correlates with poor prognosis and the methylation status. J Pathol 2003;201:487-495. 
18 Seidel C, Bartel F, Rastetter M, et al. Alterations of cancer-related genes in soft tissue sarcomas: hypermethylation of RASSF1A is frequently detected in leiomyosarcoma and associated with poor prognosis in sarcoma. Int J Cancer 2005;104:442-447.

19 Fleming ID, Cooper JS, Henson DE. Soft tissue sarcoma. In: American Joint Committee on Cancer (eds). Cancer Staging Manual, 5th edn. LippincottRaven: Philadelphia, PA, 1998, pp 149-156.

20 Lo KW, Kwong J, Hui ABY, et al. High frequency of promoter hypermethylation of RASSF1A in nasopharyngeal carcinoma. Cancer Res 2001;61:3877-3881.

21 Simpson DJ, Clayton R, Farrell WE. Preferential loss of death associated protein kinase expression in invasive pituitary tumours is associated with either $\mathrm{CpG}$ island methylation or homozygous deletion. Oncogene 2002; 21:1217-1224.

22 Esteller M, Corn PG, Urena JM, et al. Inactivation of glutathione S-transferase P1 gene by promoter hypermethylation in human neoplasia. Cancer Res 1998;58: 4515-4518.

23 Soria JC, Lee HY, Lee JI, et al. Lack of PTEN expression in non-small cell lung cancer could be related to promoter methylation. Clin Cancer Res 2002;8:1178-1184.

24 Fleisher AS, Esteller M, Wang S, et al. Hypermethylation of the $h M L H 1$ gene promoter in human gastric cancers with microsatellite instability. Cancer Res 1999;59:1090-1095.

25 Kang GH, Shim YH, Ro JY. Correlation of methylation of the $h M L H 1$ promoter with lack of expression of hMLH1 in sporadic gastric carcinoma with replication error. Lab Invest 1999;79:903-909.

26 Esteller M, Tortola S, Toyota M, et al. Hypermethylation-associated inactivation of $p 14 A R F$ is independent of p16INK4a methylation and p53 mutational status. Cancer Res 2000;60:129-133.
27 Simpson DJ, Hibberts NA, McNicol AM, et al. Loss of $\mathrm{pRb}$ expression in pituitary adenomas is associated with methylation of RB1 CpG island. Cancer Res 2000; 60:1211-1216.

28 Matsukura S, Miyazaki K, Yakushiji H, et al. Combined loss of expression of O6-methylguanine-DNA methyltransferase and hMLH1 accelerates progression of hepatocellular carcinoma. J Surg Oncol 2003;82:194-200.

29 Jones PA, Laird PW. Cancer epigenetics comes of age. Nat Genet 1999;21:163-167.

30 Baylin SB, Herman JG. DNA hypermethylation in tumorigenesis: epigenetics joins genetics. Trends Genet 2000;16:168-174.

31 Pegg AE. Mammalian O6-alkylguanine-DNA alkyltransferase regulation and importance in response to alkylating carcinogenic and therapeutic agents. Cancer Res 1990;50:6119-6129.

32 Day III RS, Ziolkowski CH, Scudiero DA, et al. Defective repair of alkylated DNA by human tumor and SV40-transformed human cell strains. Nature (London) 1980;288:724-727.

33 Fornace Jr AJ, Papathanasiou MA, Hollander MC, et al. Expression of the O6-methylguanine DNA methyltransferase gene MGMT in MER+ and MER - human tumor cells. Cancer Res 1990;50:7908-7911.

34 Esteller M, Hamilton SR, Burger PC, et al. Inactivation of the DNA repair gene O6-methylguanine-DNA methyltransferase by promoter hypermethylation is a common event in primary human neoplasia. Cancer Res 1999;59:793-797.

35 Esteller M, Toyota M, Sanchez-Cespedes M, et al. Inactivation of the DNA repair gene O6-methylguanineDNA methyltransferase by promoter hypermethylation is associated with $\mathrm{G}$ to $\mathrm{A}$ mutations in K-ras in colorectal tumorigenesis. Cancer Res 2000;60: 2368-2371. 